CLINICAL STUDY

\title{
Estradiol acutely inhibits whole body lipid oxidation and attenuates lipolysis in subcutaneous adipose tissue: a randomized, placebo-controlled study in postmenopausal women
}

Lars Christian Gormsen ${ }^{1,2}$, Christian Høst ${ }^{1}$, Britta Eilersen Hjerrild ${ }^{1}$, Steen Bønløkke Pedersen ${ }^{1}$, Søren Nielsen ${ }^{1}$, Jens Sandahl Christiansen ${ }^{1}$ and Claus Højbjerg Gravholt ${ }^{1}$

${ }^{1}$ Medical Research Laboratories, Department of Endocrinology and Internal Medicine and ${ }^{2}$ Department of Nuclear Medicine and PET Centre, Aarhus University Hospital, Norrebrogade, DK-8000 Aarhus C, Denmark

(Correspondence should be addressed to L C Gormsen at Department of Nuclear Medicine and PET Centre, Aarhus University Hospital; Email: lars.christian.gormsen@ki.au.dk)

\begin{abstract}
Context: Estradiol $\left(\mathrm{E}_{2}\right)$ promotes and maintains the female phenotype characterized by subcutaneous fat accumulation. There is evidence to suggest that this effect is due to increased anti-lipolytic $\alpha 2 \mathrm{~A}-$ adrenergic receptors, but whether this requires long-term exposure to $\mathrm{E}_{2}$ or is an immediate effect is not clear.

Objective: To study acute effects of a single dose $(4 \mathrm{mg})$ of $17 \beta-\mathrm{E}_{2}$ on regional and systemic lipolysis. Methods: Sixteen postmenopausal women (age, $59 \pm 5$ years; weight, $67 \pm 10 \mathrm{~kg}$; and BMI, $24.8 \pm 2.9$ ) were studied in a crossover design: i) placebo and ii) $4 \mathrm{mg} \mathrm{E}_{2}$. Basal and adrenaline-stimulated regional lipolysis was assessed by microdialysis and substrate oxidation rates by indirect calorimetry. Tissue biopsies were obtained to assess lipoprotein lipase activity and mRNA expression of adrenergic, estrogen, cytokine, and vascular reactivity receptors.

Results: Acute $\mathrm{E}_{2}$ stimulation significantly attenuated catecholamine-stimulated lipolysis in femoral subcutaneous adipose tissue (interstitial glycerol concentration (micromole/liter) ANOVA time vs treatment interaction, $P=0.01$ ) and lipolysis in general in abdominal adipose tissue (ANOVA treatment alone, $P<0.05)$. $\mathrm{E}_{2}$ also reduced basal lipid oxidation $((\mathrm{mg} / \mathrm{kg}$ per $\mathrm{min})$ placebo, $0.58 \pm 0.06$ vs $\left.E_{2}, 0.45 \pm 0.03 ; P=0.03\right)$ and induced a significantly higher expression of anti-lipolytic a2A-adrenergic receptor mRNA $(P=0.02)$ in skeletal muscle tissue as well as an upregulation of eNOS (NOS3) mRNA $(P=0.02)$.

Conclusion: $\mathrm{E}_{2}$ acutely attenuates the lipolytic response to catecholamines in subcutaneous adipose tissue, shifts muscular adrenergic receptor mRNA toward anti-lipolytic $\alpha 2 \mathrm{~A}$-receptors, decreases whole body lipid oxidation, and enhances expression of markers of vascular reactivity.
\end{abstract}

European Journal of Endocrinology 167 543-551

\section{Introduction}

Estradiol $\left(E_{2}\right)$ is the female sex steroid with effects on primary and secondary female sex organs. $E_{2}$ also has direct antioxidant effects (1), changes vascular reactivity $(2,3)$, interacts with vascular smooth muscle $(4,5)$, and reduces the level of circulating cholesterol (6) and free fatty acids (FFAs) (7). Some of these effects are acute, taking place within minutes or hours (8), whereas the beneficial effects on lipid metabolism may be related to more prolonged effects of $E_{2}$ on muscle and fat distribution. Thus, the reduced muscle power observed after menopause (9) is readily counteracted by female hormone therapy (HT) containing estrogens (10), which also prevents abdominal fat accumulation
(11). Abdominal or visceral fat accumulation is associated with insulin resistance and dyslipidemia, notably elevated triglycerides (TGs), and high LDLcholesterol (12).

Exactly how $\mathrm{E}_{2}$ modulates fat partitioning and redistribution is still not completely clear. Studies in transsexuals treated with $\mathrm{E}_{2}$ for a full year have demonstrated that lipolytic activity is reduced in both abdominal and femoral adipocytes during basal conditions (13). Likewise, 2 months of $\mathrm{E}_{2}$ treatment significantly reduces whole body lipolysis in postmenopausal women assessed by whole body palmitate turnover (14). This effect may be due to an increased number of anti-lipolytic $\alpha$-adrenergic receptors and a decreased number of lipolytic $\beta$-adrenergic receptors 
(15), corroborated by the observation that norepinephrine-stimulated lipolysis in the abdominal region is attenuated when oral $E_{2}$ is administered (16). A number of long-term replacement studies thus suggest that $\mathrm{E}_{2}$ to some extent modulates body composition via a gradual shift in catecholamine receptor composition favoring anti-lipolysis.

However, $\mathrm{E}_{2}$ may act more acutely as demonstrated by Van Pelt et al. (17), who administered $E_{2}$ i.v. and observed significantly diminished adipose tissue regional lipolysis assessed by microdialysis. This suggests that $\mathrm{E}_{2}$ not only acts via nuclear but also via membrane-bound receptors, which has indeed been demonstrated (18). However, to our knowledge, no group has hitherto studied whether this acute attenuation of regional tissue lipolysis is translated into decreased whole body lipid oxidation. In addition, no attempts to link regional microdialysis data to mRNA expression of lipid flux controlling catecholamine and estrogen receptors (ERs) have been done. The purpose of this study was therefore to study the effects of a single dose $(4 \mathrm{mg})$ of $\mathrm{E}_{2}$ on regional adipose tissue lipolysis assessed by microdialysis and whole body lipid turnover assessed by indirect calorimetry. As an addition to previous studies, we aimed to link any such findings to changes in catecholamine receptor mRNA expression. It was our primary hypothesis that a single dose of $\mathrm{E}_{2}$ would result in significantly attenuated lipolysis, oxidation, and lipolytic catecholamine receptor mRNA expression.

\section{Materials and methods}

\section{Subjects}

Sixteen healthy postmenopausal women (age, $59 \pm 5$ years; weight, $67 \pm 10 \mathrm{~kg}$; and BMI, $24.8 \pm 2.9$ ) not on hormone replacement therapy were recruited through advertizing. All had normal routine biochemistry and had been postmenopausal at least 1 year preceding the study. Subjects with FSH levels exceeding the detection limits of our assay were excluded. All subjects received oral and written information concerning the study before giving written informed consent. The protocol was approved by the Aarhus County Ethical Scientific Committee (\#2002-0242). Study subjects were recruited over two periods with eight subjects recruited through 2005-2006 and another eight subjects recruited in 2008. Data on very LDL-TG (VLDL-TG) kinetics from the last eight subjects have previously been published (19).

\section{Experimental protocol}

The study was carried out as a single-blinded, placebocontrolled, randomized trial (Fig. 1). The participants

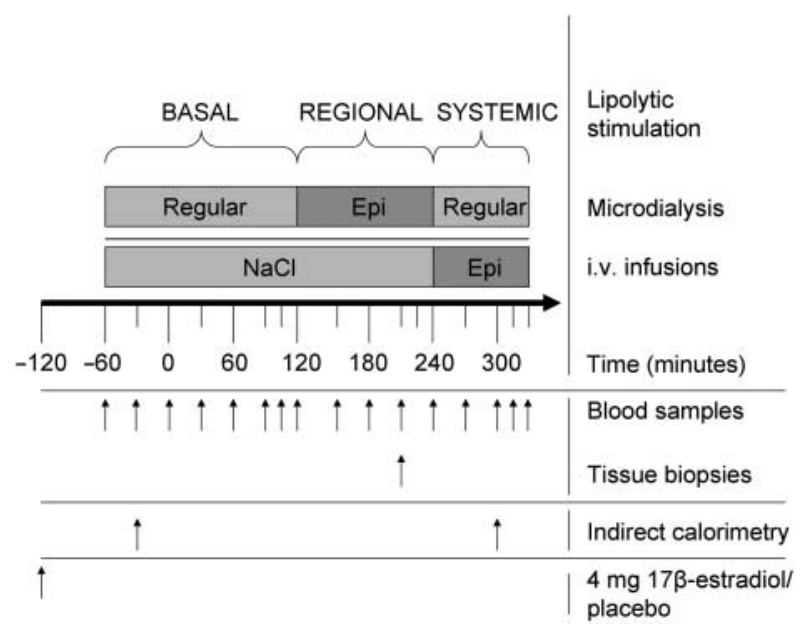

Figure 1 Study protocol. Participants were studied for a total of $6.5 \mathrm{~h}$ under basal conditions (180 $\mathrm{min}$ ), conditions of regionally stimulated lipolysis (120 min), and systemically stimulated lipolysis (90 min). Biopsies were performed at peak estradiol concentrations $(t=210 \mathrm{~min})$.

were instructed not to perform any physical exercise or ingest alcohol 1 day before the start of the study.

$\mathrm{E}_{2}$ (4 mg) or placebo was administered orally at $t=-120$ after an overnight fast $(\sim 10 \mathrm{~h})$. Two intravenous catheters (Venflon; Viggo, Helsingborg, Sweden) were inserted in the antecubital vein of the right arm and in a dorsal vein of the right hand. The latter was placed in a heated box at $65^{\circ} \mathrm{C}$, allowing for arterialized blood samples to be drawn. At $t=-90$, microdialysis catheters were placed.

From $t=0 \mathrm{~min}$ and onward, blood samples were drawn every $30 \mathrm{~min}$ and analyzed for plasma glucose (PG), FFAs, cortisol, GH, insulin, C-peptide, and catecholamines. Sampling from the microdialysis catheters (interstitial fluid) commenced at $t=0 \mathrm{~min}$, allowing for $60 \mathrm{~min}$ of equilibration to minimize the influence of local edema and hemorrhage. The sampling was performed every $30 \mathrm{~min}$ and continued until $t=330 \mathrm{~min}$. From $t=120-240 \mathrm{~min}$, adrenaline was added to the microdialysis perfusion fluid at a final concentration of $10 \mu \mathrm{m} / \mathrm{l}$ to enhance lipolysis locally (20).

From $t=240-330 \mathrm{~min}$, adrenaline was infused i.v. at a rate of $0.15 \mathrm{nmol} / \mathrm{kg}$ per min (21). We aimed at limiting the increase in heart rate to no more than $50 \%$ during this study period, which was accomplished in all subjects.

Indirect calorimetry (Deltatrac Metabolic Monitor, Datex, Helsinki, Finland) with a ventilated hood at $40 \mathrm{l} / \mathrm{min}$ was performed, during the basal period $(t=-30-0 \mathrm{~min})$ and during the last $30 \mathrm{~min}$ of the systemically stimulated lipolysis $(t=300-330 \mathrm{~min})$. Energy expenditure (EE), respiratory exchange ratio, and 24-h excretion of urea in urine were measured, and glucose, protein, and lipid oxidation were calculated (22). 


\section{Tissue biopsies}

At $t=210$, a muscle biopsy was obtained from the vastus lateralis muscle with a Bergström biopsy needle under local anesthesia ( $1 \%$ lidocaine), a small incision having been made through the skin and muscle sheath $15-20 \mathrm{~cm}$ above the knee. A total amount of $\sim 200 \mathrm{mg}$ muscle was aspirated, cleaned for blood (within $15 \mathrm{~s}$ ), and snap-frozen in liquid nitrogen. Muscle biopsies were stored at $-80{ }^{\circ} \mathrm{C}$ until analyzed. Immediately following the muscle biopsy, a subcutaneous fat biopsy from the periumbilical region was obtained by liposuction and snap-frozen in liquid nitrogen.

\section{Microdialysis}

After application of a local analgesic (Lidocaine), microdialysis catheters (CMA-60; CMA, Stockholm, Sweden) were inserted in subcutaneous adipose tissue in the periumbilical and femoral region. The microdialysis catheters have a molecular cutoff of $20 \mathrm{kDa}$ and a membrane length of $30 \mathrm{~mm}$ and were perfused at a flow rate of $1 \mu \mathrm{l} / \mathrm{min}$ using CMA-107 perfusion pumps (CMA). We attempted to asses the relative recovery of interstitial glycerol by the internal reference method with $\left[{ }^{3} \mathrm{H}\right]$ glycerol (23). However, as adrenaline added to the perfusate introduced a dramatic variability in individual recovery rates (data not shown), interstitial glycerol concentrations were not corrected for relative recovery and may thus have been slightly underestimated. Perfusate and dialysate were counted using a Wallac 1450 liquid scintillation counter applying the Optiphase supermix scintillation fluid. Changes in interstitial glycerol concentration can be taken as an index of lipolysis $(24,25,26)$.

\section{Adipose tissue blood flow}

Subcutaneous adipose tissue blood flow (ATBF) was assessed in the abdominal and femoral region by the local ${ }^{133} \mathrm{Xe}$ washout method (27). In short $\sim 1 \mathrm{Mbq}$ ${ }^{133} \mathrm{Xe}$ was injected into the area of interest and based on the rate constant $(k)$ of the washout curve, ATBF was calculated as ATBF $=k \times \lambda \times 100(\mathrm{ml} / 100 \mathrm{~g}$ per min $)$, where $\lambda$ is the tissue to blood partition coefficient for ${ }^{133} \mathrm{Xe}$ at equilibrium; counts were collected every second and a straight line was fitted through the experimental points in a semilogarithmic diagram as a function of time. $\lambda$ was calculated as $\lambda=0.22 \times \mathrm{SFT}+$ 2.99, where SFT is the skin fold thickness of the abdominal adipose tissue (28).

\section{Lipoprotein lipase activity measurements}

Adipose tissue lipoprotein lipase (LPL) activity was determined essentially as described previously (29). Briefly, $200 \mathrm{mg}$ adipose tissue was homogenized in

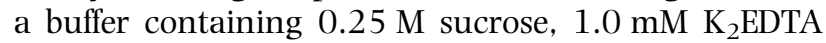

(pH 7.4) at $4^{\circ} \mathrm{C}$, and the homogenate was centrifuged $20 \mathrm{~min}$ at $12000 \mathrm{~g}$ at $4{ }^{\circ} \mathrm{C}$. The LPL activity in the postmitochondrial supernatant was determined by estimating the specific hydrolysis of $\left[{ }^{14} \mathrm{C}\right]$ triolein after 60 min of incubation. FFAs were extracted from the incubation mixture as described previously (29) and measured by liquid scintillation counting.

Muscle LPL activity was measured in $\sim 30 \mathrm{mg}$ of the muscle biopsy. This was cut (on ice) into small pieces (3-5 mg) and placed in incubation tubes. The tissue was incubated in a heparin-containing (200 IU L21) medium with a serum-activated triolein emulsion with 14C-triolein as tracer and albumin as acceptor of released fatty acids. The mixture was incubated for $30 \mathrm{~min}$ on an ice bath and then for a further $120 \mathrm{~min}$ at $37^{\circ} \mathrm{C}$ in a shaking water bath. LPL activity was measured on the same day to eliminate the influence of day-to-day variation.

\section{Isolation of RNA}

Adipose tissue samples $(200 \mathrm{mg})$ were homogenized in TRIzol reagent (Life Technologies, Inc.), and total RNA was extracted following the manufacturer's protocol. RNA was quantitated by measuring absorbency at 260 and $280 \mathrm{~nm}$, and purity was assured by a ratio of 1.8 or higher. The integrity of the RNA was checked by visual inspection of the two ribosomal RNAs on an ethidium bromide-stained agarose gel.

\section{Real-time RT-PCR for mRNA analysis}

Reverse transcription was performed using random hexamer primers at $23{ }^{\circ} \mathrm{C}$ for $10 \mathrm{~min}$ and $42{ }^{\circ} \mathrm{C}$ for $60 \mathrm{~min}$ and was terminated by increasing the temperature to $95^{\circ} \mathrm{C}$ for $10 \mathrm{~min}$, as described by the manufacturer (GeneAmp RNA PCR Kit from PerkinElmer Cetus, Norwalk, CT, USA). Then, PCR mastermix containing the specific primers and Taq DNA polymerase (HotStar Taq; Qiagen, Inc.) were added. Real-time quantitation of target gene (XO)-to- $\beta$-actin (RO) mRNA was performed with a SYBR-Green real-time PCR assay (Qiagen, Inc.) using an ICycler from Bio-Rad (Bio-Rad Laboratories) as described previously (30). The XO and RO mRNA were amplified in separate tubes. The increase in fluorescence was measured in real time during the extension step. The threshold cycle $(\mathrm{Ct})$ was calculated, and the relative gene expression was calculated essentially as described in the User Bulletin no. 2, 1997, from Perkin-Elmer. Briefly, the X0-to-R0 ratio in each sample before amplification was calculated as $\mathrm{X} 0 / \mathrm{R} 0=k \times 1 /\left(2^{\Delta \mathrm{Ct}}\right)$, where $\Delta \mathrm{Ct}$ is the difference between Ct-target and Ct-reference and $k$ is a constant, set to 1. All samples were amplified in duplicate. A similar setup was used for negative controls, except that the reverse transcriptase was omitted, and no PCR products were detected under these conditions. The following targets were measured: $\alpha 2 \mathrm{~A}$ - receptor, 
$\beta 1$-receptor, $\beta 3$-receptor, ER $\alpha, \mathrm{ER} \beta$, uncoupling protein 2 (UCP2), UCP3, adiponectin, hormone-sensitive lipase (HSL), LPL, interleukin 6, vascular cell adhesion molecule 1, intercellular adhesion molecule, monocyte chemoattractant protein, and endothelial derived nitric oxide synthase (eNOS).

\section{Assays}

PG was analyzed in duplicate using the glucose oxidase method (Beckman Coulter, Palo Alto, CA, USA). Measurements were performed immediately during the study. Insulin was measured with an immunoassay (DAKO, Glostrup, Denmark). Serum FFA was determined by a colorimetric method employing a commercial kit (Wako Pure Chemical Industries, Neuss, Germany). Serum $17 \beta-\mathrm{E}_{2}$ was analyzed using a commercial ultrasensitive assay (Spectria Estradiol Sensitive RIA, Orion Diagnostica Espoo, Finland), with detection limits of $0.005 \mathrm{nmol} / \mathrm{l}$. All samples from an individual patient were analyzed in the same assay. Adrenaline and noradrenaline were measured by HPLC (31). Glycerol in the microdialysis dialysate was measured in duplicate by an automated spectrophotometric kinetic enzymatic analyzer (CMA-600).

\section{Statistical analysis}

Results from blood samples (hormones and metabolites) are expressed as time-averaged values during the basal (0-240 min) and stimulated period $(t=240-330 \mathrm{~min})$. To investigate the impact of $\mathrm{E}_{2}$ on regional lipolysis, we used a mixed model with fixed effect terms treatment (placebo or $\mathrm{E}_{2}$ ) and time and the interaction of time and treatment as the term of interest (time $\times$ treatment). Subjects were included as random effects to account for within-subject correlation. All other between-treatment differences were assessed by Student's $t$-test (parametric data) or Wilcoxon signed rank test (nonparametric data). $P$ values $<0.05$ were considered significant. Statistical analysis was performed using SPSS version 11 (SPSS Inc., IBM, Somers, NY, USA). Parametric data are presented as mean \pm s.E.M. and nonparametric data as medians (range).

\section{Results}

\section{Hemodynamics}

Basal heart rate (pulse $\mathrm{BASAL}_{\mathrm{B}}$ (beats/min), $61 \pm 2$ (placebo) vs $\left.61 \pm 2\left(\mathrm{E}_{2}\right) ; P=0.57\right)$, systolic blood pressure (systolic BASAL $_{\text {( }} \mathrm{mmHg}$ ): placebo, $127 \pm 4$ vs $\mathrm{E}_{2}$, $127 \pm 3 ; P=0.93)$, and diastolic blood pressure (diastolic (mmHg): placebo, $79 \pm 3$ vs $\mathrm{E}_{2}, 79 \pm 2$; $P=0.77$ ) was unaffected by $E_{2}$. Likewise, the expected increase in heart rate and decrease in blood pressure induced by the systemic adrenaline infusion was similar

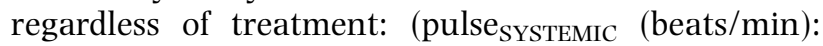

placebo, $73 \pm 3$ vs E $_{2}, 73 \pm 2 ; P=0.78$ ), systolic $_{\text {SYSTEMIC }}$ (mmHg): placebo, $117 \pm 4$ vs $\left.E_{2}, 117 \pm 4 ; P=0.95\right)$,

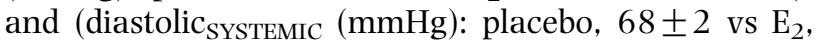
$68 \pm 2 ; P=0.84)$.

\section{Circulating hormones}

Participants had low to undetectable $\mathrm{E}_{2}$ concentrations $(0.08 \pm 0.01 \mathrm{nmol} / \mathrm{l})$ on the placebo study day (Fig. 2), while acute $\mathrm{E}_{2}$ resulted in an approximate fourfold rise in $E_{2}$ concentrations with peak values occurring at $t=300 \mathrm{~min}(0.35 \pm 0.06 \mathrm{mmol} / \mathrm{l})$. Adrenaline concentrations were low through basal and regionally stimulated lipolysis (adrenalin ( $\mathrm{pg} / \mathrm{ml})$ : placebo, $32.5 \pm 3.4$ vs $\left.E_{2}, 35.6 \pm 4.6 ; P=0.54\right)$ and rose sharply to a plateau value (adrenalin $(\mathrm{pg} / \mathrm{ml})$ : placebo, 308.6 \pm 34.8 vs $E, 300.9 \pm 36.0 ; P=0.83)$ after initiation of the adrenaline infusion. Noradrenaline concentrations were comparable on both study days and only increased modestly during the adrenaline infusion. Insulin levels tended to decrease through basal and regionally stimulated lipolysis on both study days (insulin (pmol/l): placebo, $22.5 \pm 2.3$ vs $\left.E_{2}, 23.6 \pm 2.6 ; P=0.55\right)$ with a similar increase in response to elevated glucose levels observed during the adrenaline infusion (insulin ( $\mathrm{pmol} / \mathrm{l})$ : placebo, 28.5 \pm 3.1 vs E $\left._{2}, 28.6 \pm 2.8 ; P=0.97\right)$.

\section{Metabolites}

FFA levels were similar on both study days through the basal and regionally stimulated period (FFA ( $\mu \mathrm{mol} / \mathrm{l})$ :
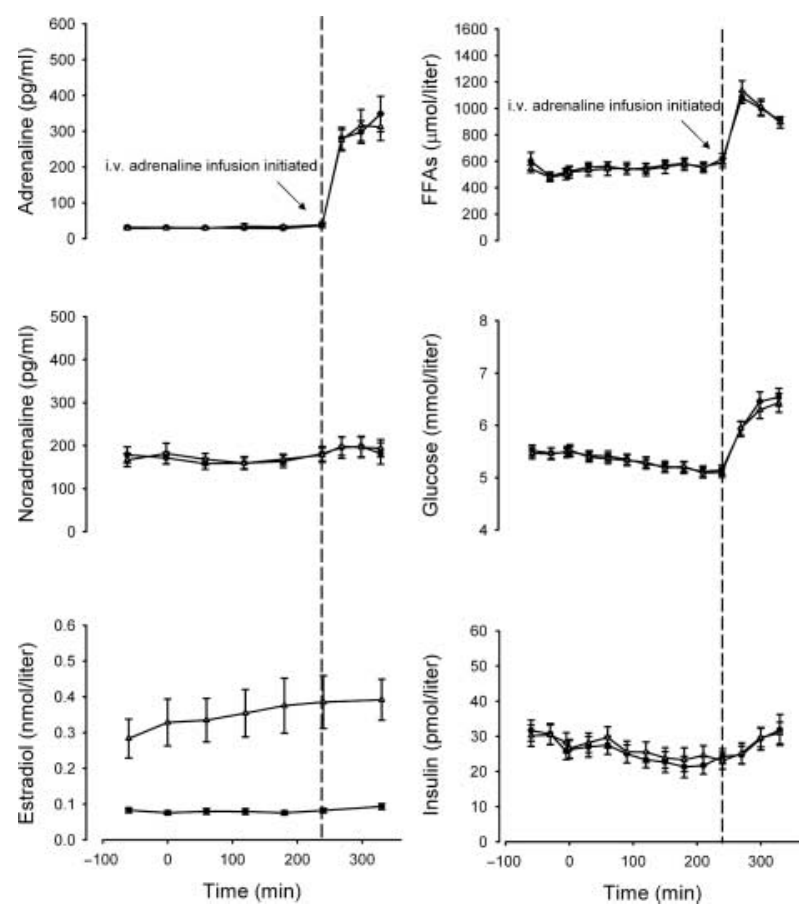

Figure 2 Circulating hormones and metabolites. Filled circle, placebo; open triangle, estradiol. Error bars are \pm S.E.M., $n=16$. 
placebo, $583 \pm 33$ vs $E_{2}, 575 \pm 34 ; P=0.86$; Fig. 2). Adrenaline infusion doubled FFA levels within $30 \mathrm{~min}$ to $\sim 1.200 \mu \mathrm{mol} / \mathrm{l}$ with a subsequent gradual decrease to $\sim 900 \mu \mathrm{mol} / \mathrm{l}$ at $t=330 \mathrm{~min}$. Blood glucose concentrations tended to decrease slightly through the basal and regionally stimulated period and rose sharply after initiation of the adrenaline infusion (Fig. 2). No significant differences in glucose levels between treatment days were observed.

\section{Regional lipolysis}

Three distinct patterns of adrenaline-induced lipolysis were observed (Fig. 3): i) in muscle, basal interstitial glycerol concentrations, and thus lipolysis, were unaffected by $\mathrm{E}_{2}$ and the regional and systemic adrenaline stimulation elicited similar increases in interstitial glycerol concentrations (micromole/liter; repeated measurements ANOVA (RM-ANOVA; time vs treatment), $P=\mathrm{NS}$ ). ii) In femoral adipose tissue, a similar lack of effect was observed in the basal period, whereas the lipolytic response to adrenaline-stimulated lipolysis was significantly attenuated when subjects were treated with $\mathrm{E}_{2}$ (RM-ANOVA (time vs treatment), $P=0.01)$. iii) In abdominal adipose tissue, by contrast, interstitial glycerol concentrations were lower after $E_{2}$ treatment already during the basal period and remained significantly subdued during local adrenaline and systemic stimulated lipolysis (RM-ANOVA (treatment), $P<0.05)$. This anti-lipolytic effect was not enhanced by adding epinephrine to the perfusate (RM-ANOVA during the regional period (time vs treatment), $P=0.34$ ).

\section{Substrate oxidation (indirect calorimetry)}

During basal conditions, $\mathrm{E}_{2}$ treatment significantly decreased whole body lipid oxidation rates (LIPOXbasal (mg/kg per $\mathrm{min}):$ placebo, $0.58 \pm 0.06$ vs $\mathrm{E}_{2}, 0.45$ $\pm 0.03 ; P=0.03$; Fig. 4). As expected, glucose oxidation was increased, albeit not significantly (GOXbasal (mg/kg per $\mathrm{min})$ : placebo, $1.31 \pm 0.11$ vs $\mathrm{E}_{2}, 1.48$ $\pm 0.10 ; P=0.10)$. The adrenaline infusion elicited an immediate $\sim 20 \%$ increase in EE regardless of treatment (data not shown), which could be entirely attributed to increased lipid oxidation. However, during systemic adrenaline stimulation, no difference was observed in neither lipid (LIPOXsystemic ( $\mathrm{mg} / \mathrm{kg}$ per min): placebo, $0.87 \pm 0.09$ vs $\left.E_{2}, 0.87 \pm 0.08 ; P=0.98\right)$ nor glucose (GOXsystemic ( $\mathrm{mg} / \mathrm{kg}$ per $\mathrm{min})$ : placebo, $1.06 \pm 0.19$ vs $E_{2}, 1.13 \pm 0.14 ; P=0.60$ ) oxidation (Fig. 5).

Basal total EE tended to decrease during $\mathrm{E}_{2}$ treatment (EEbasal (kcal/24 h): placebo, 1297 \pm 51 vs $\left.E_{2}, \quad 1237 \pm 40 ; \quad P=0.06\right)$, whereas this was not observed during adrenaline-stimulated conditions (EEsystemic (kcal/24 h): placebo, 1472 \pm 56 vs $\left.E_{2}, 1504 \pm 57 ; P=0.31\right)$.

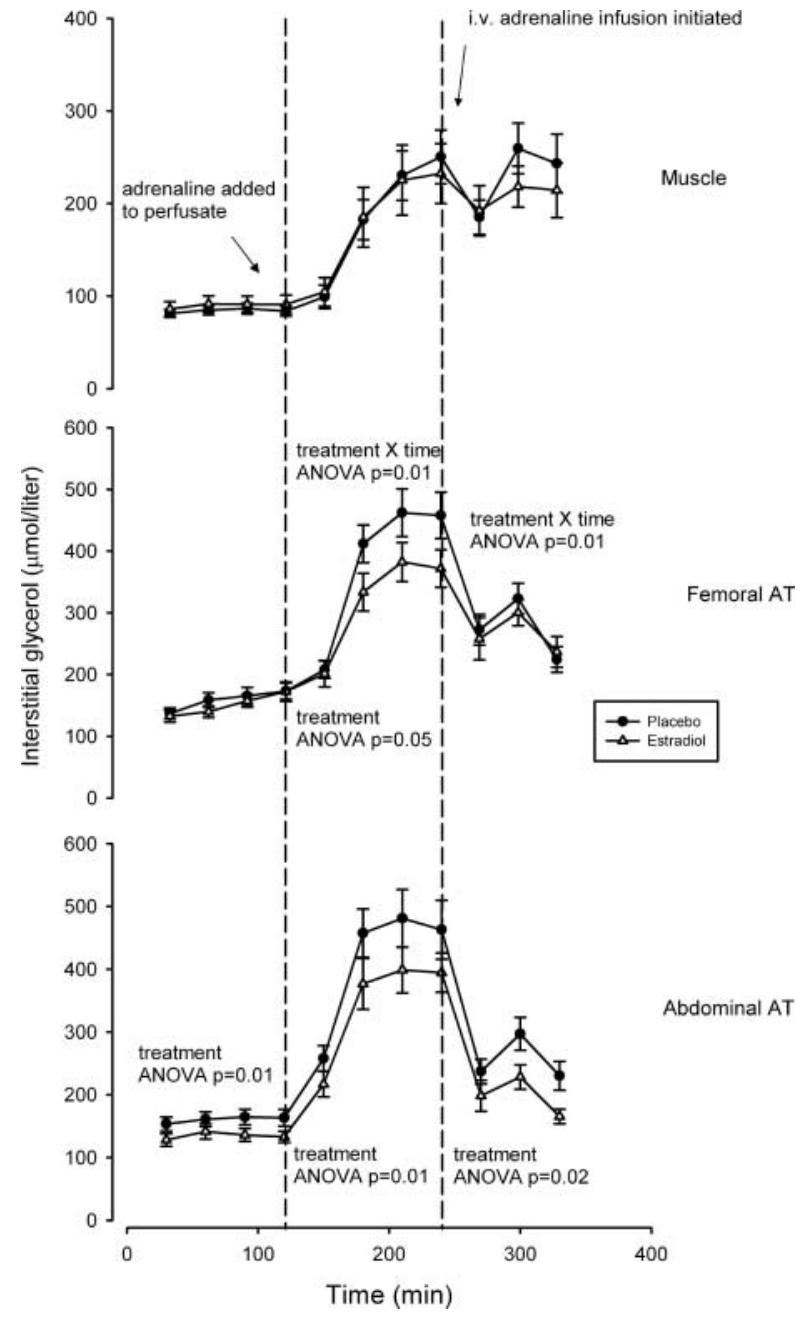

Figure 3 Regional lipolysis assessed by microdialysis. From $t=120-240$ adrenaline was added to the perfusate in order to enhance lipolysis and from $t=240-330$ adrenaline was infused i.v. The impact of estradiol on regional lipolysis was analyzed by repeated measurements ANOVA with time $\times$ treatment or treatment as the parameter of interest. Error bars are \pm S.E.M., $n=16$. Filled circle, placebo; open triangle, estradiol.

\section{LPL activity and mRNA expression}

$\mathrm{E}_{2}$ treatment resulted in a trend toward reduced LPL activity in skeletal muscle $(\sim 26 \%, P=0.09)$ whereas this was not the case in adipose tissue. No convincing trends were observed in LPL mRNA levels in muscle tissue or fat.

\section{Catecholamine receptor gene expression}

$\mathrm{E}_{2}$ resulted in significantly increased anti-lipolytic $\alpha 2$-adrenergic receptor mRNA in muscle (Fig. 5B) and also tended to increase lipolytic $\beta 1$-adrenergic receptor mRNA in that tissue (D). However, we were unable to detect any measurable effect of $\mathrm{E}_{2}$ on the same receptor mRNA in adipose tissue (Fig. 5A and $\mathrm{C}$ ). 

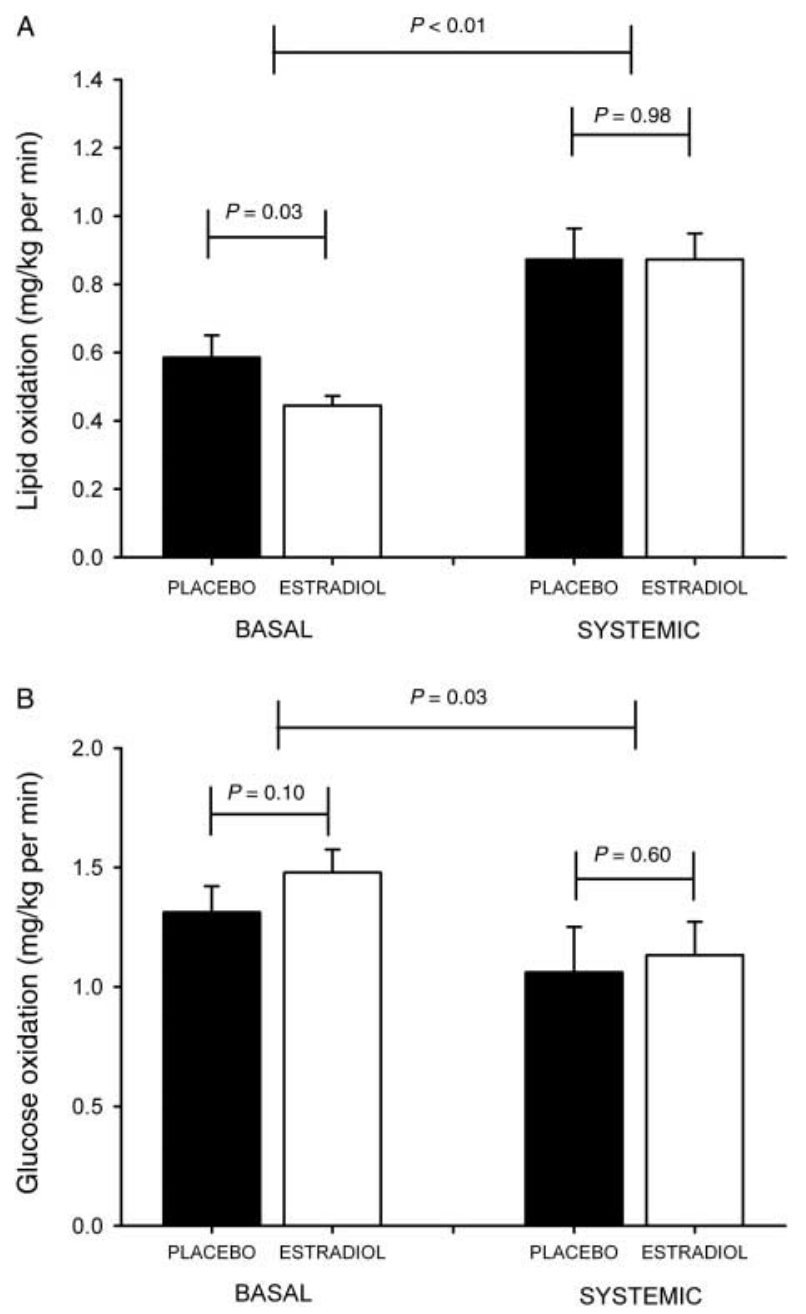

Figure 4 Substrate oxidation rates. (A) lipid oxidation. $E_{2}$ administration significantly decreased basal lipid oxidation. (B) Glucose oxidation. No difference was observed between placebo and $E_{2}$. All error bars are \pm S.E.M., $n=15$ (one subject suffered from claustrophobia and could not cooperate). 'Basal' refers to $t=-60$ to $120 \mathrm{~min}$ whereas 'systemic' refers to systemic stimulation with adrenaline from $t=240$ to $330 \mathrm{~min}$.

\section{Markers of vascular reactivity (ATBF and eNOS mRNA)}

During basal conditions, ATBF in both the femoral $\left(\operatorname{ATBF}_{\text {BASAL }}(\mathrm{ml} / 100 \mathrm{~g}\right.$ per min): placebo, $1.01 \pm 0.18$ vs $\left.E_{2}, 1.04 \pm 0.13 ; P=0.90\right)$ and the abdominal $\left(\operatorname{ATBF}_{\text {BASAL }}(\mathrm{ml} / 100 \mathrm{~g}\right.$ per min): placebo, $0.93 \pm 0.11$ vs $\left.E_{2}, 0.84 \pm 0.13 ; P=0.58\right)$ region was comparable. However, during systemic adrenaline infusion, $E_{2}$ treatment resulted in significantly diminished ATBF in the abdominal region $\left(\mathrm{ATBF}_{\text {SYSTEMIC }}(\mathrm{ml} / 100 \mathrm{~g}\right.$ per $\min )$ : placebo, $\quad 1.37 \pm 0.15$ vs $\mathrm{E}_{2}, \quad 0.98 \pm 0.16$; $P=0.01)$, whereas no such effect was observed in the femoral region $\left(\operatorname{ATBF}_{\text {SYSTEMIC }}(\mathrm{ml} / 100 \mathrm{~g}\right.$ per min): placebo, $1.50 \pm 0.24$ vs $E_{2}, 1.64 \pm 0.17 ; P=0.44$; Fig. 6 ).
In muscle, $\mathrm{E}_{2}$ significantly increased eNOS (NOS3) mRNA expression $(P=0.02)$. No significant effect was observed in adipose tissue.

\section{Discussion}

The principal results from this study show that a single dose of $\mathrm{E}_{2}$ in postmenopausal women resulted in significant and immediate metabolic responses: i) the lipolytic response to local catecholamine stimulation in subcutaneous femoral adipose tissue was attenuated; ii) overall lipolysis was attenuated in subcutaneous abdominal adipose tissue; iii) an immediate shift in muscle adrenergic receptor expression toward antilipolytic $\alpha 2$ A-receptors occurred; iv) whole body fuel combustion shifted from lipid oxidation toward glucose consumption and a trend toward diminished LPL activity and thus extraction of lipids from circulating lipoproteins was observed; and v) finally, $\mathrm{E}_{2}$ altered markers of vascular reactivity by stimulating eNOS mRNA expression in muscle tissue and decreasing adrenaline-stimulated ATBF in the abdominal region.

Menopause causes an extensive array of modulations in the typical female fat distribution, most notably a shift in fat depots from the lower body and subcutaneous depots to the upper body and visceral depots (32). Female sex HT abolishes this potentially deleterious effect of menopause and the accompanying decrease in estrogen levels (11), but whether this effect of $E_{2}$ on lipid metabolism is indirect or direct is not obvious. Adipocytes express both $\alpha$ - and $\beta$-ERs (33) and longterm $\mathrm{E}_{2}$ treatment results in a shift in adrenergic receptor composition increasing the number of antilipolytic $\alpha 2 \mathrm{~A}$-receptors (15). Thus, the effect of $\mathrm{E}_{2}$ on lipid metabolism and hence on body composition
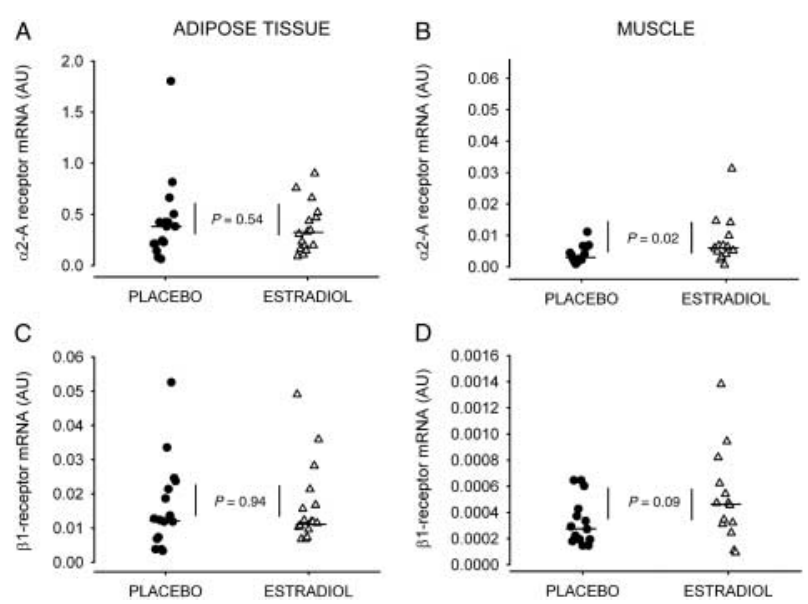

Figure 5 Anti-lipolytic $\alpha 2 \mathrm{~A}$ - and $\beta 1$-receptor mRNA expression. Median values are represented by vertical lines as appropriate, $n=14$ (two subjects did not wish to have muscle biopsies taken). All units are arbitrary units $(\mathrm{AU})$. Adipose tissue was obtained from the periumbilical region. 

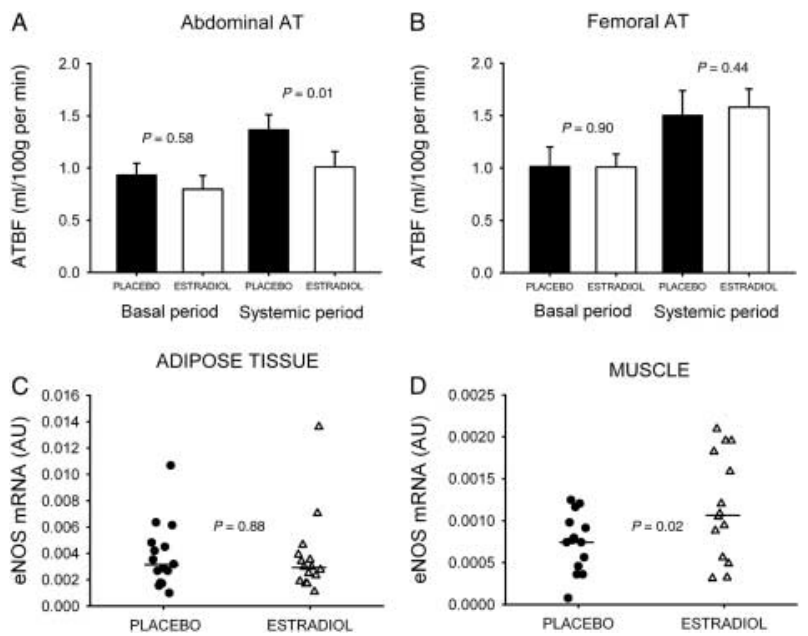

Figure 6 Markers of vascular reactivity. (A) Abdominal adipose tissue blood flow (ATBF) during systemic adrenaline infusion was significantly suppressed after estradiol treatment compared with placebo conditions. (B) Femoral ATBF did not show a similar trend as no differences between treatment days were observed. Error bars are \pm S.E.M., $n=16$. ( $C$ and $D)$ No difference was observed in eNOS mRNA expression in adipose tissue, whereas estradiol clearly upregulated eNOS mRNA in muscle, $n=14$. Data are presented as point plots with median values as vertical lines.

appears to be direct and mediated via ERs. These observations have led to renewed interest in adipocyte receptor subgroups, and recently, Garcia Dos Santos et al. (18) demonstrated the existence of a membranebound ER $\alpha$. In that study, the authors demonstrated that physiological concentrations of $E_{2}$ rapidly lead to activated p42/p44 mitogen-activated protein kinase and that this effect could be blocked by an estrogen antagonist. Furthermore, infusion of conjugated estrogens increases insulin action within hours and decreases plasma glycerol concentrations during a hyperinsulinemic euglycemic clamp (34), rendering it plausible that a range of signaling cascades is activated acutely by $\mathrm{E}_{2}$. It can therefore be speculated that adrenergic receptors as a result of $\mathrm{E}_{2}$ administration are translocated to the cell surface of adipocytes within hours of stimulation. Cross talk between activated membrane-bound ERs and adrenergic receptors could therefore potentially facilitate a more rapid effect of $E_{2}$ than the classical pathway through nuclear receptors. It is therefore a major finding of this study that adrenaline-stimulated lipolysis was indeed markedly attenuated in subcutaneous adipose tissue when studied only $4 \mathrm{~h}$ after administration of a single dose of $\mathrm{E}_{2}$. Although we failed to detect a significant upregulation of adipose tissue anti-lipolytic adrenergic receptor mRNA, this may therefore reflect the abovementioned rapid nongenomic effects of $\mathrm{E}_{2}$ and that a longer observation period would have led to increases in the mRNA level.
Adipocyte function is tightly regulated by a range of hormones and enzyme systems. Hyperinsulinemia favors TG accumulation through inhibition of the HSL, whereas catecholamine stimulation through adrenergic $\beta 1$ - and $\beta 2$-receptors stimulates lipolysis via increased HSL activity. Counteracting the lipolytic effects of adrenergic $\beta$-receptors, stimulation of the $\alpha 2 \mathrm{~A}$ receptor initiates a cascade blocking adenylate cyclase and ultimately resulting in inhibition of the HSL mimicking the effects of insulin (35). The ratio of lipolytic $\beta$-receptors to anti-lipolytic $\alpha$-receptors is shifted by exposure to $E_{2}$ depending on the location of the fat depot: in visceral fat, $\mathrm{E}_{2}$ has no detectable effect on this ratio, whereas a change toward anti-lipolytic $\alpha$-receptors is observed in subcutaneous fat depots (15). This could suggest that the decline in estrogen observed after menopause promotes lipolysis and contributes to reduced subcutaneous adipose tissue. Data presented here demonstrate that in skeletal muscle a shift toward anti-lipolytic $\alpha 2 \mathrm{~A}$-receptors takes place on mRNA level within hours after $E_{2}$ exposure and in adipose tissue the same trend was observed.

In line with the findings of most $(14,36,37,38,39)$, but not all (40), previous studies, whole body lipid oxidation was significantly decreased in our volunteers during $\mathrm{E}_{2}$ treatment. However, whereas previous studies have been designed to study more long-term effects of estrogens with typical treatment periods lasting 1-12 months, this is to our knowledge the first study in humans reporting immediate effects of estrogen on lipid oxidation. Interestingly, animal studies have indicated that $E_{2}$ administered for brief periods results in significantly reduced hepatic carnitine palmitoyltransferase 1 (CPT1 (CPT1A)) mRNA expression (41) and thus reduces lipids transported into mitochondria for oxidation. Our results suggest that hepatic and/or peripheral lipid oxidation is effectively reduced within hours after $\mathrm{E}_{2}$ treatment, an effect that must be largely independent of gene up or down regulation.

Somewhat to our surprise, $E_{2}$ reduced the known stimulatory effect of systemic adrenaline infusion on ATBF (42). However, as $\mathrm{E}_{2}$ convincingly reduces lipid oxidation and subcutaneous lipolysis, it is intuitively appealing that it should also reduce ATBF to regional fat depots. $\mathrm{E}_{2}$ treatment was also associated with a significant increase in eNOS mRNA expression in muscle, an effect that has been demonstrated before in animal and cell studies $(43,44)$. This may serve to further divert blood from adipose tissue toward muscle.

The data presented herein demonstrate that $\mathrm{E}_{2}$ has immediate and therefore most likely nongenomic effects on lipid metabolism. In summary, $\mathrm{E}_{2}$ : i) attenuates the lipolytic response to adrenaline in subcutaneous femoral adipose tissue and overall lipolysis in subcutaneous abdominal adipose tissue; ii) inhibits basal whole body lipid oxidation; iii) upregulates anti-lipolytic a2A-receptor mRNA in muscle; and iv) reduces the stimulatory effect of adrenaline on ATBF. 


\section{Declaration of interest}

L Gormsen, B E Hjerrild, S B Pedersen, and S Nielsen have no disclosures. C H Gravholt has received lecture fees from Novo Nordisk. J S Christiansen has served as a consultant and received lecture fees from Novo Nordisk, Pfizer, and Ipsen.

\section{Funding}

The study was supported by grants from the Danish Health Research Council, grant number 22-01-0395, and the Novo Nordisk Foundation.

\section{Author contribution statement}

All studies were performed at The Medical Research Laboratories, Aarhus University Hospital, Denmark. L C Gormsen designed the experiments, performed metabolic studies, collected data, interpreted data, and wrote the manuscript. C Høst performed metabolic studies, collected data, interpreted data, and revised the manuscript. B E Hjerrild performed metabolic studies and collected data. S B Pedersen collected and interpreted data and revised the manuscript. J S Christiansen interpreted data and revised the manuscript. S Nielsen collected data, interpreted data, and revised the manuscript. $\mathrm{C} \mathrm{H}$ Gravholt conceived the experiment, designed the study, collected and interpreted data, and revised the manuscript.

\section{Acknowledgements}

The authors thank Annette Mengel for excellent technical assistance. Roche Diagnostics kindly donated the microdialysis catheters.

\section{References}

1 Sack MN, Rader DJ \& Cannon RO III. Oestrogen and inhibition of oxidation of low-density lipoproteins in postmenopausal women. Lancet $1994343 \quad 269-270 . \quad$ (doi:10.1016/S0140-6736(94) 91117-7)

2 Collins P, Rosano GM, Sarrel PM, Ulrich L, Adamopoulos S, Beale CM, McNeill JG \& Poole-Wilson PA. 17ß-Estradiol attenuates acetylcholine-induced coronary arterial constriction in women but not men with coronary heart disease. Circulation 199592 24-30. (doi:10.1161/01.CIR.92.1.24)

3 Gilligan DM, Badar DM, Panza JA, Quyyumi AA \& Cannon RO III. Acute vascular effects of estrogen in postmenopausal women. Circulation 199490 786-791. (doi:10.1161/01.CIR.90.2.786)

4 Losordo DW, Kearney M, Kim EA, Jekanowski J \& Isner JM. Variable expression of the estrogen receptor in normal and atherosclerotic coronary arteries of premenopausal women. Circulation 199489 1501-1510. (doi:10.1161/01.CIR.89.4. 1501)

5 Selzman CH, Gaynor JS, Turner AS, Johnson SM, Horwitz LD, Whitehill TA \& Harken AH. Ovarian ablation alone promotes aortic intimal hyperplasia and accumulation of fibroblast growth factor. Circulation 199898 2049-2054. (doi:10.1161/01.CIR.98. 19.2049)

6 Terauchi M, Honjo H, Mizunuma H \& Aso T. Effects of oral estradiol and levonorgestrel on cardiovascular risk markers in postmenopausal women. Archives of Gynecology and Obstetrics 2012285 1647-1656. (doi:10.1007/s00404-012-2222-9)

7 Gaspard UJ, Wery OJ, Scheen AJ, Jaminet C \& Lefebvre PJ. Longterm effects of oral estradiol and dydrogesterone on carbohydrate metabolism in postmenopausal women. Climacteric 19992 93-100. (doi:10.3109/13697139909025572)
8 Simpson ER, Misso M, Hewitt KN, Hill RA, Boon WC, Jones ME, Kovacic A, Zhou J \& Clyne CD. Estrogen - the good, the bad, and the unexpected. Endocrine Reviews 200526 322-330. (doi:10.1210/er.2004-0020)

9 Rutherford OM \& Jones DA. The relationship of muscle and bone loss and activity levels with age in women. Age and Ageing 199221 286-293. (doi:10.1093/ageing/21.4.286)

10 Phillips SK, Rook KM, Siddle NC, Bruce SA \& Woledge RC. Muscle weakness in women occurs at an earlier age than in men, but strength is preserved by hormone replacement therapy. Clinical Science $1993 \mathbf{8 4}$ 95-98.

11 Haarbo J, Marslew U, Gotfredsen A \& Christiansen C. Postmenopausal hormone replacement therapy prevents central distribution of body fat after menopause. Metabolism 199140 1323-1326. (doi:10.1016/0026-0495(91)90037-W)

12 Rader DJ. Effect of insulin resistance, dyslipidemia, and intraabdominal adiposity on the development of cardiovascular disease and diabetes mellitus. American Journal of Medicine $2007 \mathbf{1 2 0}$ S12-S18. (doi:10.1016/j.amjmed.2007.01.003)

13 Elbers JM, de Jong S, Teerlink T, Asscheman H, Seidell JC \& Gooren LJ. Changes in fat cell size and in vitro lipolytic activity of abdominal and gluteal adipocytes after a one-year cross-sex hormone administration in transsexuals. Metabolism $1999 \mathbf{4 8}$ 1371-1377. (doi:10.1016/S0026-0495(99)90146-4)

14 Jensen MD, Martin ML, Cryer PE \& Roust LR. Effects of estrogen on free fatty acid metabolism in humans. American Journal of Physiology. Endocrinology and Metabolism 1994266 E914-E920.

15 Pedersen SB, Kristensen K. Hermann PA, Katzenellenbogen JA \& Richelsen B. Estrogen controls lipolysis by up-regulating $\alpha 2 \mathrm{~A}-$ adrenergic receptors directly in human adipose tissue through the estrogen receptor $\alpha$. Implications for the female fat distribution. Journal of Clinical Endocrinology and Metabolism $2004 \mathbf{8 9}$ 1869-1878. (doi:10.1210/jc.2003-031327)

16 Lindberg UB, Crona N, Silfverstolpe G, Bjorntorp P \& RebuffeScrive M. Regional adipose tissue metabolism in postmenopausal women after treatment with exogenous sex steroids. Hormone and Metabolic Research 199022 345-351. (doi:10.1055/s-20071004917)

17 Van Pelt RE, Gozansky WS, Hickner RC, Schwartz RS \& Kohrt WM Acute modulation of adipose tissue lipolysis by intravenous estrogens. Obesity 200614 2163-2172. (doi:10.1038/oby. 2006.253)

18 Garcia Dos Santos E, Dieudonne MN, Pecquery R, Le Moal V, Giudicelli Y \& Lacasa D. Rapid nongenomic $\mathrm{E}_{2}$ effects on p42/p44 MAPK, activator protein-1, and cAMP response element binding protein in rat white adipocytes. Endocrinology 2002143 930-940. (doi:10.1210/en.143.3.930)

19 Gormsen LC, Host C, Hjerrild BE, Gravholt CH \& Nielsen S. Acute estrogen exposure does not affect basal very low-density lipoprotein-triglyceride production or oxidation in postmenopausal women. European Journal of Endocrinology $2010163421-426$ (doi:10.1530/EJE-10-0551)

20 Stich V, Pelikanova T, Wohl P, Sengenes C, Zakaroff-Girard A, Lafontan M \& Berlan M. Activation of $\alpha 2$-adrenergic receptors blunts epinephrine-induced lipolysis in subcutaneous adipose tissue during a hyperinsulinemic euglycemic clamp in men. American Journal of Physiology. Endocrinology and Metabolism 2003 285 E599-E607.

21 Stallknecht B, Simonsen L, Bulow J, Vinten J \& Galbo H. Effect of training on epinephrine-stimulated lipolysis determined by microdialysis in human adipose tissue. American Journal of Physiology. Endocrinology and Metabolism 1995269 E1059-E1066.

22 Frayn KN. Calculation of substrate oxidation rates in vivo from gaseous exchange. Journal of Applied Physiology 198355 628-634.

23 Lonnroth P \& Strindberg L. Validation of the 'internal reference technique' for calibrating microdialysis catheters in situ. Acta Physiologica Scandinavica 1995153 375-380. (doi:10.1111/ j.1748-1716.1995.tb09875.x) 
24 Arner P \& Bolinder J. Microdialysis of adipose tissue. Journal of Internal Medicine 1991230 381-386. (doi:10.1111/j.13652796.1991.tb00461.x)

25 Hagstrom-Toft E, Enoksson S, Moberg E, Bolinder J \& Arner P. Absolute concentrations of glycerol and lactate in human skeletal muscle, adipose tissue, and blood. American Journal of Physiology 1997273 E584-E592.

26 Jansson PA, Smith U \& Lonnroth P. Interstitial glycerol concentration measured by microdialysis in two subcutaneous regions in humans. American Journal of Physiology. Endocrinology and Metabolism $1990 \mathbf{2 5 8}$ E918-E922.

27 Larsen OA, Lassen NA \& Quaade F. Blood flow through human adipose tissue determined with radioactive xenon. Acta Physiologica Scandinavica 196666 337-345. (doi:10.1111/j.1748-1716. 1966.tb03208.x)

28 Bulow J, Jelnes R, Astrup A, Madsen J \& Vilmann P. Tissue/blood partition coefficients for xenon in various adipose tissue depots in man. Scandinavian Journal of Clinical and Laboratory Investigation 198747 1-3.

29 Hietanen E \& Greenwood MR. A comparison of lipoprotein lipase activity and adipocyte differentiation in growing male rats. Journal of Lipid Research 197718 480-490.

30 Pedersen SB, Bruun JM, Kristensen K \& Richelsen B. Regulation of $\mathrm{UCP} 1$, UCP2, and UCP3 mRNA expression in brown adipose tissue, white adipose tissue, and skeletal muscle in rats by estrogen. Biochemical and Biophysical Research Communications 2001288 191-197. (doi:10.1006/bbrc.2001.5763)

31 Carstensen E \& Yudkin JS. Platelet catecholamine concentrations after short-term stress in normal subjects. Clinical Science $1994 \mathbf{8 6}$ 35-41.

32 Ley CJ, Lees B \& Stevenson JC. Sex- and menopause-associated changes in body-fat distribution. American Journal of Clinical Nutrition 199255 950-954.

33 Price TM \& O'Brien SN. Determination of estrogen receptor messenger ribonucleic acid (mRNA) and cytochrome P450 aromatase mRNA levels in adipocytes and adipose stromal cells by competitive polymerase chain reaction amplification. Journal of Clinical Endocrinology and Metabolism $1993 \quad 77$ 1041-1045. (doi:10.1210/jc.77.4.1041)

34 Van Pelt RE, Gozansky WS, Schwartz RS \& Kohrt WM. Intravenous estrogens increase insulin clearance and action in postmenopausal women. American Journal of Physiology. Endocrinology and Metabolism 2003285 E311-E317.

35 Arner P. Human fat cell lipolysis: biochemistry, regulation and clinical role. Best Practice $\mathcal{E}$ Research. Clinical Endocrinology $\mathcal{E}$ Metabolism 200519 471-482. (doi:10.1016/j.beem.2005.07. 004)
36 dos Reis CM, de Melo NR, Meirelles ES, Vezozzo DP \& Halpern A. Body composition, visceral fat distribution and fat oxidation in postmenopausal women using oral or transdermal oestrogen. Maturitas $2003 \quad 46$ 59-68. (doi:10.1016/S0378-5122(03) 00159-2)

37 Lwin R, Darnell B, Oster R, Lawrence J, Foster J, Azziz R \& Gower BA. Effect of oral estrogen on substrate utilization in postmenopausal women. Fertility and Sterility $2008 \mathbf{9 0}$ 1275-1278. (doi:10.1016/j.fertnstert.2007.07.1317)

38 O'Sullivan AJ, Crampton LJ, Freund J \& Ho KK. The route of estrogen replacement therapy confers divergent effects on substrate oxidation and body composition in postmenopausal women. Journal of Clinical Investigation $1998 \mathbf{1 0 2} 1035-1040$. (doi:10.1172/JCI2773)

39 O'Sullivan AJ, Hoffman DM \& Ho KK. Estrogen, lipid oxidation, and body fat. New England Journal of Medicine 1995333 669-670. (doi:10.1056/NEJM199509073331018)

40 Huang DS \& O'Sullivan AJ. Short-term oral oestrogen therapy dissociates the growth hormone/insulin-like growth factor-I axis without altering energy metabolism in premenopausal women. Growth Hormone E IGF Research 200919 162-167. (doi:10. 1016/j.ghir.2008.08.009)

41 Gower BA, Nagy TR, Blaylock ML, Wang C \& Nyman L. Estradiol may limit lipid oxidation via Cpt 1 expression and hormonal mechanisms. Obesity Research 200210 167-172. (doi:10.1038/ oby.2002.26)

42 Samra JS, Simpson EJ, Clark ML, Forster CD, Humphreys SM, Macdonald IA \& Frayn KN. Effects of epinephrine infusion on adipose tissue: interactions between blood flow and lipid metabolism. American Journal of Physiology. Endocrinology and Metabolism 1996271 E834-E839.

43 Gonzales RJ, Walker BR \& Kanagy NL. 17ß-Estradiol increases nitric oxide-dependent dilation in rat pulmonary arteries and thoracic aorta. American Journal of Physiology. Lung Cellular and Molecular Physiology $20012 \mathbf{2 8 0}$ L555-L564.

44 Zerr-Fouineau M, Jourdain M, Boesch C, Hecker M, Bronner C \& Schini-Kerth VB. Certain progestins prevent the enhancing effect of $17 \beta$-estradiol on NO-mediated inhibition of platelet aggregation by endothelial cells. Arteriosclerosis, Thrombosis, and Vascular Biology 200929 586-593. (doi:10.1161/ATVBAHA.108. 178004)

Received 14 May 2012

Revised version received 17 July 2012

Accepted 6 August 2012 